\title{
Wetlands for a Sustainable Urban Future: Insights from Pondicherry, South India
}

\author{
Raphaël Mathevet $^{* 1,2}$, Simon Targowla ${ }^{1}$, Anbarashan Munisamy ${ }^{1}$, Venkatasubramanian \\ Govindan', Ayyappan Narayanan', Nicolas Bautès ${ }^{1}$ \\ ${ }^{1}$ French Institute of Pondicherry (IFP) - UMIFRE 21 CNRS-MAEE / USR 3330 - 11, St. Louis street, P.B. \\ 33, Pondicherry 605001, India \\ ${ }^{2}$ CEFE, CNRS, Univ Montpellier, Univ Paul Valéry Montpellier 3, EPHE, IRD, Montpellier, France \\ *Corresponding author: raphael.mathevet@ifpindia.org |ORCID: https://orcid.org/0000-0002-1778-1080
}

How to cite this paper: Mathevet, R., Targowla, S., Munisamy, A., Govindan, V., Narayanan, A. and Bautès, N. (2020). Wetlands for a Sustainable Urban Future: Insights from Pondicherry, South India. Grassroots Journal of Natural Resources, 3(4): 74-93. Doi:

https://doi.org/10.33002/nr2581.6853.03045

Received: 05 October 2020

Reviewed: 17 October 2020

Provisionally Accepted: 28 October 2020

Revised: 11 November 2020

Finally Accepted: 21 November 2020

Published: 20 December 2020

Copyright $\odot 2020$ by author(s)

This work is licensed under the Creative Commons Attribution International License (CC BY 4.0).

http://creativecommons.org/licenses/by/4.0/
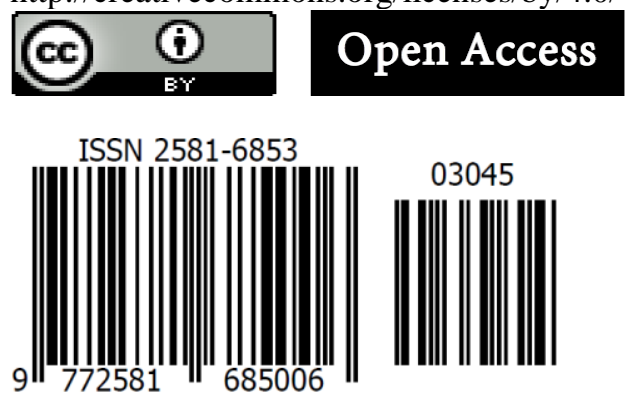

\begin{abstract}
Wetland ecosystems hold an important part of the world's biodiversity and are complex social-ecological systems. Aiming to understand interdependencies among their components and to define management policies, the social-ecological trajectory of Oussudu lake - a wetland of Pondicherry region in South India - was reconstructed and analysed. During the last decades, this wetland has transformed from an irrigation tank to a lake to cater biodiversity conservation and recreation. The environmental history highlights a governance change that has contributed to "black boxing" the wetland's functional environment and to conceal major water issues at regional and local levels. This study emphasizes the importance of implementing an approach that combines the management of this urban lake commons with a multi-scalar, socio-ecological and multistakeholder analysis. A trade-off on the seasonal water regime between different users - including fauna and flora - has to be found.

\section{Keywords}

Urban lake; Wetland; Water management; Political ecology, Biodiversity conservation; Regional planning
\end{abstract}




\section{Introduction}

Hosting a tremendous diversity of landscapes, habitats and species, wetlands are among the most valuable, fragile and productive ecosystems on Earth (Moore, 2006; Ghermandi et al., 2010; Russi et al., 2012). However, these spaces are facing increasing anthropogenic pressures and are considered, along with tropical forests, as some of the world's most threatened ecosystems (Turner et al., 2000; Malty and Barker, 2009). The 20 $0^{\text {th }}$ century recorded a 64-71\% loss in wetland's area depending on their type and location (Davidson, 2014). Despite the Ramsar Convention on wetlands of international importance for birds, and the wide legal arsenal developed by many countries, wetlands are still in decline. The largest wetland loss has occurred in Asia with about 2.65 million km² (Davidson, 2014; Hu et al., 2017). Covering about 58.2 million hectares, India's wetlands are under an increasing threat (Foote, Pandey and Krogman, 1996; Prasad et al., 2002). The main identified sources of stress are urbanisation, industrialisation and agricultural intensification (Bassi et al., 2014) and, more recently, tourism expansion. For the purpose of sustainable development, numerous legislations, policies and institutions have been created to protect and manage these wetlands (i.e., The Wetlands Conservation and Management Rules, 2010 and 2017 notified by the Ministry of Environment and Forest). However, regular environmental crises keep questioning the efficiency of public action for nature protection. Generalised corruption and lack of means for action are often designated as the main causes of failures in conservation programmes worldwide (Smith et al., 2003; Doshi and Ranganathan, 2017). In this context, this article focuses on the construction of issues related to the conservation and management of wetlands and conflicts related to the development of protected areas (bird sanctuaries) in South India.

Tamil Nadu is the third most urbanised state in India with about 35 million people living in cities representing $48 \%$ of the national population (see Census of India, 2011). The rural landscapes of Tamil Nadu host a unique network of artificial wetlands generally gathered under the category of tanks, which were built hundreds of years ago for irrigation purposes (Adiceam, 1966). Tanks also provide numerous other services to local communities, such as fishing, hunting, grass collecting, tree plantations and grazing on the banks of the water body. In the region, tanks were considered as village institutions, strengthening the socio-political organisation of the village (Aubriot, 2013). However, for several decades this organisation has been reshaped by a water management crisis at all levels of the agrarian social structure. In this context, the environmental history of Oussudu Lake (or Ousteri in Tamil, eri meaning lake, tank), which is an interstate lake between Tamil Nadu and Pondicherry, is studied. The spatial extend of the lake is almost equal in between the states, and is one of the largest tank of the Pondicherry region. The recent history of Oussudu Lake is that of one of numerous suburban wetlands facing unprecedented and increasing pressures from urbanisation (D'Souza and Nagendra, 2011; Nagendra and Ostrom, 2014; Surya, 2016; Lele and Sengupta, 2018). Pondicherry population growth was $28 \%$ during the 2001-2011 decade and the population of Puducherry reached 1.2 million inhabitants (see Census of India, 2011). As this wetland was declared a bird sanctuary (in 2008 by Pondicherry and in 2015 by Tamil Nadu) for the purpose of protecting, and developing wildlife and its environment, the question of a trade-off between potable water, irrigation, tourism and biodiversity is raised, especially in the context of the city's growth and increasing demand for land, potable water and waste dumping areas. The current development of urban areas is a major worldwide concern for wetland conservation and wise use. While the theme of 2018 World Wetland Day was "wetland for sustainable urban future", the social-ecological trajectory of Oussudu Lake may highlight typical governance issues faced by 
suburban wetlands in South Asia (Hettiarachchi et al., 2019), China (Lee, 2014), Africa (Matamanda et al., 2018), Europe (Miho, 2018; Salizzoni et al., 2020) and USA (Moore et al., 2003).

This paper presents first a brief description of the implemented method and the social-ecological context of the case study. Second, the history of the wetland over the last centuries is explored and reveals the dynamics of interdependencies. A particular attention is paid to the ways that previous planning and development policies led to some feedback and unexpected consequences. To conclude, the conceptual and practical lessons that this analysis provides are emphasised.

\section{Methodology}

\section{The Framework}

In the context of global change, it is necessary that any environmental study should focus on socialecological systems (SES) for an understanding of the impact of interdependences and feedbacks on the resilience of SES (Berkes and Folke, 1998; Steffen et al., 2004). SES are complex systems involving multi-scalar and multi-level processes with non-linear feedbacks characterized by high levels of uncertainty (Gallopín et al., 1989; Anderies et al., 2013). To address this complexity, various conceptual tools were developed in different disciplines and fields of research, especially in sustainability sciences (Kates, 2011). However, because wetlands are dynamic SES that are situated, produced and power-laden landscapes (Mathevet, 2004), the SES analysis should be supplemented by an exploration of how power shapes the SES dynamics. The source of environmental problems often lies in past changes in use and control over the various resources, and their systemic long-term impacts (Blaikie and Brookfield, 1987; Robbins, 2012). Taking the historical dimensions of social, political, economic, and ecological drivers is imperative when investigating biodiversity conservation problems in engineered wetlands. Social conflicts are often the result of a blend of social relationships, access rights and control policies (Neumann, 2005). Because the ecologies of wetlands are dependent on the cumulative impacts of interactions between human decisions and actions in and around the wetland itself, analysis in this article adopts an interdisciplinary methodology, rooted in human geography and wetland ecology, and it takes a historical political ecology approach (Mathevet et al., 2015).

The study used both secondary and primary data in assessing all aspects of the wetland dynamics over time. Various data sources were used such as present-day field evidence from ecological monitoring, social surveys, observations and informal interviews, historical evidence collected from archives, reports and old maps of the region from the $16^{\text {th }}$ century to the present time. Aiming to synthetize the existing material, a systematic review of literature was first carried out, exploring scientific papers and books. It also included expertise reports and media releases, data related to farming systems and practices, irrigation and regional planning (shared with collaborators working in social sciences on water management issues in the region for 30 years at the French Institute of Pondicherry). In addition, 23 interviews were conducted with natural resource specialists (i.e., ecologists and social scientists) who have extensively studied the area, local activists involved in nature protection and its study, representatives of Forest Department, Public Work Department and Tourism Departments, local landowners, and fishermen or hunters. Interviews were semistructured and focused on a short professional trajectory, the understanding of the present and past social-ecological dynamics of the lake, the identification of the main trends and drivers, and 
potential wetland attributes. Moreover, in September 2017 a monthly water bird census was launched to assess community composition change and to compare observed data with trends identified by the main stakeholders themselves. Informal discussions were conducted with local stakeholders, such as fishermen, livestock breeders or landowners in the vicinity of Oussudu Lake.

\section{Case study and main issues}

With an urban land-cover reaching $68 \%$ of the Puducherry Union Territory, the latter is one of the most urbanised Indian territories according the Ministry of Housing and Urban Affairs, Government of India. Surface water in the region is characterized by two main rivers: Gingee and Pennaiyar. 84 tanks, including 59 system-tanks and 25 non-system tanks, were reported in 2004 (TRPP, 2004). Located $10 \mathrm{~km}$ west of Pondicherry, near the village of Oussudu, the study site is a suburban freshwater wetland developed from a tank built during the Vijaynagar reigns $\left(14-16^{\text {th }}\right.$ century) for irrigation purposes (Perennou, 1990). Oussudu tank lies at the bottom of a slight natural depression. The lake is shallow; water levels oscillate between summer drawdown and a maximum of $3.5 \mathrm{~m}$. The water body has a total area of 850 ha, including 390 ha in the Pondicherry territory and the rest in Tamil Nadu state (Figure 1). It is bordered by two dikes that carry a paved road, in the south, with very intense road traffic and, in the west, mostly a road used by villagers. The other banks resulting from the natural slope of the land are lined with crops and plantations. When the tank is not completely full, the northern sector is cultivated by the villagers while the other sectors are used for grazing the livestock. The surrounding landscape consists of rural settlements, farmlands and plantations in the Tamil Nadu part, while in the Puducherry Union Territory, the land cover is mostly urban and industrial.

Oussudu tank has to be understood as a complete irrigation system composed by the Suttukanni channel connected to Suttukanni anicut, a dam built on the Gingee river at the end of 19th century (Antony, 1982), the catchment area of $40 \mathrm{~km}^{2}$ (with upper tanks) and the irrigation canals in the command area (ayacut) of 1,538 ha are mostly used for rice cultivation. It is a system-tank fed by runoffs from the catchment (30\%), upper tanks (5\%) and by the Suthukanni canal (65\%) (Atkins, 2001).

The climatic regime is tropical monsoon with an average rainfall of 1,338 $\mathrm{mm}$ /year and average annual temperatures ranging from $24.1^{\circ} \mathrm{C}$ to $33.1^{\circ} \mathrm{C}$ (Prusty et al., 2011). Oussudu Lake thus presents seasonal variations in water surface (in average $320 \mathrm{ha}$ ) and depth $(1.2 \mathrm{~m})$, mainly driven by the north-east monsoon. The water is characterized by slight alkalinity (Sharma, 1997). The dominant water source in this area is indeed the rainwater that fills up the tanks and recharges the groundwaters. The north-east monsoon rainfall that occurs from October to December constitutes $63 \%$ of the annual rainfall (Barrat, 1999). In this climatic setting, the water tanks with their rainwater harvesting systems used to play a key role not only as a water resource for irrigation but also domestic and industrial use. Today, mainly groundwater is used for irrigation in the area (Venkatasubramanian van Klink and Richard-Ferroudji, 2017). Borewells are extracting groundwater from the 3 main aquifers of Pondicherry region: the Alluvium aquifers, Cuddalore sandstone aquifers and Vanur-Ramanathapuram sandstone aquifers. If the upper aquifers may be recharged by surface water in the Pondicherry region, the deeper aquifers are recharged by sources much farther upstream (TRPP, 2004). 


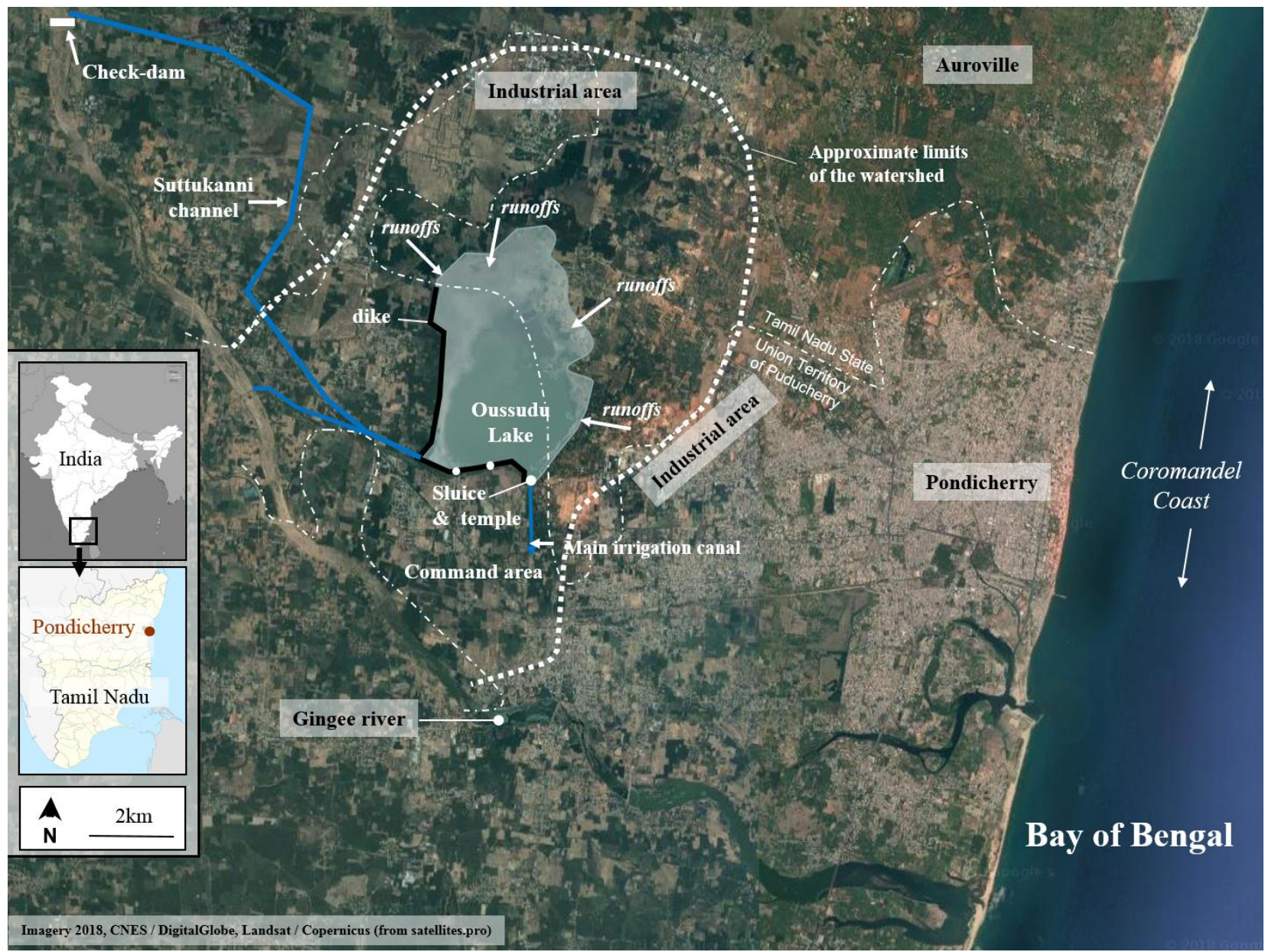

Figure 1: Location of Oussudu Lake, Pondicherry and Tamil Nadu, South India

The climate variability has a profound influence on the tank hydrology (date and time of filling, volume of water and water depths, and the date and duration of dewatering vary considerably). The tank used to collect the rains of September-December and had till recently two objectives (Perennou, 1990):

- to irrigate the crops and, in particular, the surrounding paddy fields between December and June-July in accordance with the availability of water and the farmers' demand in the command area.

- to allow infiltration recharge of the water table that supplies drinking water to Pondicherry city. However, scientific evidence confirms that the recharge occurs almost only when the tank is full (A. Selles, pers. comm., French Geological Survey, Hyderabad bureau).

According to the records of the Public Work Department (PWD), during the 1970s and 1990s the lake had to begin filling between September and December. Water levels were maximum between November and February and drying had to take place progressively between February and August. but may not occur more than once or twice per decade. The dewatering period could be different depending on whether the PWD allocated water to farmers or reserved it to recharge the groundwater table or for biodiversity conservation and tourism purposes. Moreover, the filling was generally very fast in 1 or 2 weeks depending on the rainfall and the flow of the feeding channels. Available hydrological data shows that, prior to 2004, the Oussudu reservoir was a dynamic 
seasonal wetland, temporarily flooded and mainly dry from May to September, with a few residual water bodies here and there. From 2004 to 2018, the restricted flow for downstream irrigation purposes (15 days/year) limited the dewatering process. The lake, which had not been entirely drained since 2003, was dry again in 2018, 2019 and 2020.

The water body, fringes and surrounding paddy fields and remnants of natural vegetation and afforested regions in the study area historically constituted a functional ecosystem hosting a wide diversity of wildlife habitats, under human influences (Sharma, 1997; Manimekhalan et al., 2005). Oussudu Lake is also ecologically linked to other key wetlands in the region such as Kaliveli (20 $\mathrm{km}$ north) and Bahour (17 km south). It is included in a global network of habitats for migratory birds. It is a major wintering ground for a large number of birds, especially waders and ducks, (Jhunjhunwala, 1998; Davidar, 2011; Prusty et al., 2011; Kumaran, Jagannathan and Nadarajan, 2012). The lake provides important livelihood opportunities to the local community (i.e., irrigation, drinking, bathing, washing, grazing, fishing, hunting, aesthetic, recreation and tourism). Oussudu Lake is thus identified as highly important by the International Union for Conservation of Nature (IUCN) and as Important Bird Area (IBA) by Bombay Natural History Society ${ }^{1}$ (BNHS). The wetland is also reported under the National Wetland Conservation Program (NWCP) of the Ministry of Environment, Forests and Climate Change, Government of India. The Asian Wetland Bureau included Oussudu Lake in its list of 115 significant wetlands in Asia. Oussudu Lake was declared the first bird sanctuary of Pondicherry in 2008 (Prusty et al., 2011) for the purpose of protecting, propagating and developing wildlife and its environment. The bird sanctuary perimeter was restricted to the water body and the banks of the lake. The legal protection, and prohibition of any human activities except ecotourism, were extended to the 331.79 ha area belonging to Villupuram district in 2015 (SER, 2016). The sanctuary is now under the joint management of the Pondicherry and Tamil Nadu's Forest and Wildlife Departments. The surface water and irrigation facilities are still controlled by Pondicherry PWD in coordination with the Tourism Department. However, recently the lake and its surrounding area are facing several threats and pressures from human activities. The urban development of 16 surrounding settlements, establishment of a medical college and hospital in its vicinity, set up of an amusement park and two industrial areas impact Oussudu water quality. The first industrial estate is located in the north-western part of the lake and is a mix of glass, rubber and coir industrial units, while the other is located on the eastern side on the way from Puducherry and is a mix of cosmetic industry, veterinary school, brewery and dairy (Figure 2). According to media releases (The Hindu, 2019) and expert reports (Prusty et al. 2011; SER, 2016), local people and activists, illegal fishing and hunting, industrial and domestic dumping, and agricultural and industrial water pollution impact the tank greatly and its immediate surroundings while the command area faces growing urban sprawl.

\section{Results}

\section{Reconstructing the social-ecological trajectory of Oussudu Lake}

Reconstructing the region's history of social-ecological change and showing how changes in land use, public infrastructures, water management have impacted the wetland ecology provide key

\footnotetext{
${ }^{1}$ Based in Mumbai, the BNHS is the oldest scientific organization in India, working for nature conservation since 1883. Its goal is to spread awareness about nature and science-based approach, conservation, education. Dr Salim Ali, the world-renowned ornithologist, was its former president.
} 
indications to the origins of the current problems arising from recent plans aiming both to use water and conserve biodiversity. By narrating the history of Oussudu wetland, analysis details out the emergence of a conservation landscape and how social-ecological dynamics have changed over time. It also focuses on how different social actors are impacted by conservation policy highlighting different visions of what this conservation landscape looks like socially and ecologically. Results are summed up and generalized in figure 3. It characterizes 4 periods and the associated development model and management regime of this complex SES. The dominant human activity structuring the social and ecological landscape and guiding the exploitation of natural resources constitute the development model (DM). The management regime is understood as the implicit or explicit principles, norms, rules and decision-making processes around which actors' expectations in land and natural resource management converge (Mathevet et al. 2018).

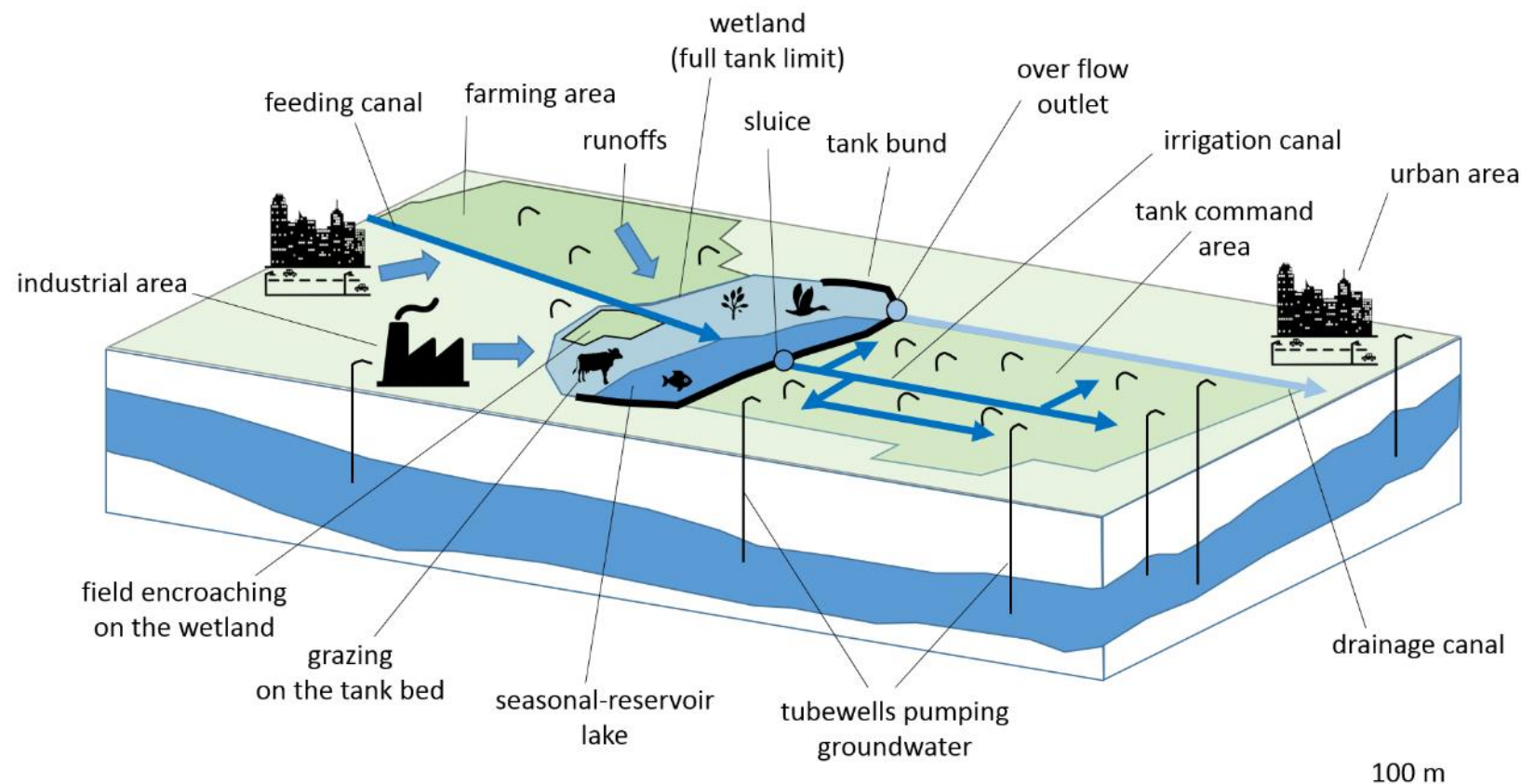

Figure 2: Sketch of a tank irrigation system in South India, showing use of surface and ground waters, and wetland conservation dimensions (adapted from Aubriot and Prabhakar, 2011).

\section{Period 1: A key tank for irrigation during the French regime (from 1670s to 1950s)}

The former agricultural development model of Pondicherry and Tamil Nadu (DM1) was based on surface water for irrigation. The agrarian space was shaped by the construction of tanks to harvest and store rainwater (Oussudu Lake and associated irrigation network). The major maintenance work in the tank was regular silt removal. Several attempts by the French administration to rationalize irrigation management were reported in the literature. The tank was renovated and enlarged in 1860 (Glaux, 1972) with an extensive system of irrigation canals was constructed during the French era (Abbasi, 1997). The management regime of tanks for irrigation was characterized by collective management, customary institutions, irrigation infrastructure maintenance, and land and water sharing of the command area (Antony, 1982; Aubriot, 2013). The public authorities led the tank maintenance, while the collective irrigation management groups in each village of the command area oversaw the irrigation canals specifically. However, tank 
management needs to be understood as the result of a competition between formal and informal institutions and between caste groups exercising power over the tank management (Prabhakar, 2007; Aubriot, 2013). Activities such as hunting, fishing, grazing and reed harvesting were practised by villagers (Scott, 1989). Wood for fuel and construction, medicinal plants, silt and reeds, and freshwater for domestic purposes were valuable benefits provided by the wetland.

Period 2: Emergence of the ground water irrigation system and the farming disconnection from surface water (from the 1950s to 1990s)

After the Indian independence (1947) and the handing over of Pondicherry to India (1954) and during the Green Revolution (1960s-1970s), technical innovations (i.e., borewells, submersible pumps), access to electricity (expansion of the electrical network in villages, free electricity for farmers) and incentive policies favoured a shift to a new agricultural development model (DM2) based on an alternative resource for irrigation (i.e., groundwater) (Antony, 1982; Marius-Gnanou, 1992). Since 1985 irrigation using surface water has almost disappeared, and, in 1992, more than 99\% of irrigated lands in Pondicherry region were reported to rely on groundwater (TRPP, 2004). Oussudu Lake and its irrigation facilities (sluices, regulators, feeder channels and irrigation canals) progressively fell into disuse (Atkins, 2001). Consequently, farmers could no longer rely on surface water, and the landless or small landholders who were unable to afford borewell installation became dependent on "water lords" for irrigation (Aubriot and Prabhakar, 2011). On one hand, rich farmers were able to invest in bores and pumps have used their free access to the ground water resource to sell it to the small and marginal farmers throughout informal water markets (Palanisami and Balasubramanian, 1998; Balasubramanian and Selvaraj, 2003). By doing so, they increased their economic power and social-political influence, coupled with their key role as decision-makers in collective management of water tanks. Several authors highlighted that the rapid decline in tank management was due to the collapse of local institutions, which was triggered by spread of motorpumps, and the villages' urbanisation (Janakarajan, 2004; Shaktivadivel, Gomathinayagam and Shah, 2004; Aubriot and Prabhakar, 2011). Thus, the management regime became individual and the access to the ground water resource was regulated by land ownership and individual economic capacity (Aubriot, 2013). This second development model progressively replaced the previous dominant one and opened a window of opportunity for nature conservation. Wildlife associated with these wetlands could be a positive externality of the construction of tanks in general. As their irrigation function is disappearing, the focus could then be on tourism and nature conservation.

\section{Period 3: A tank in disuse became a bird sanctuary (from 1990s to till date)}

Several governmental policies had influence on water use. A Tank Rehabilitation Project in Pondicherry (TRPP) was launched in September 1998 (TRPP, 2004). The project, funded by the European Commission and implemented by the Agriculture Department of Pondicherry and local communities, aimed to rehabilitate tank irrigation systems by creating the Tank Associations (TAs) to empower farmers in tank management. Oussudu Lake was selected for rehabilitation along with 79 other tanks in the Pondicherry region. The programme ended in 2004 (TRPP, 2004) and a second version of the project was implemented from 2004 to 2008. Despite these efforts, local agriculture remains dependent on groundwater irrigation. Within the region, tanks are now increasingly seen as a cultural heritage, symbolising the identity of villages, and also believed to recharge groundwater. From mid-2000s, Oussudu tank is identified as "Oussudu Lake Bird Sanctuary", a protected area for wildlife and a touristic spot near Pondicherry. 


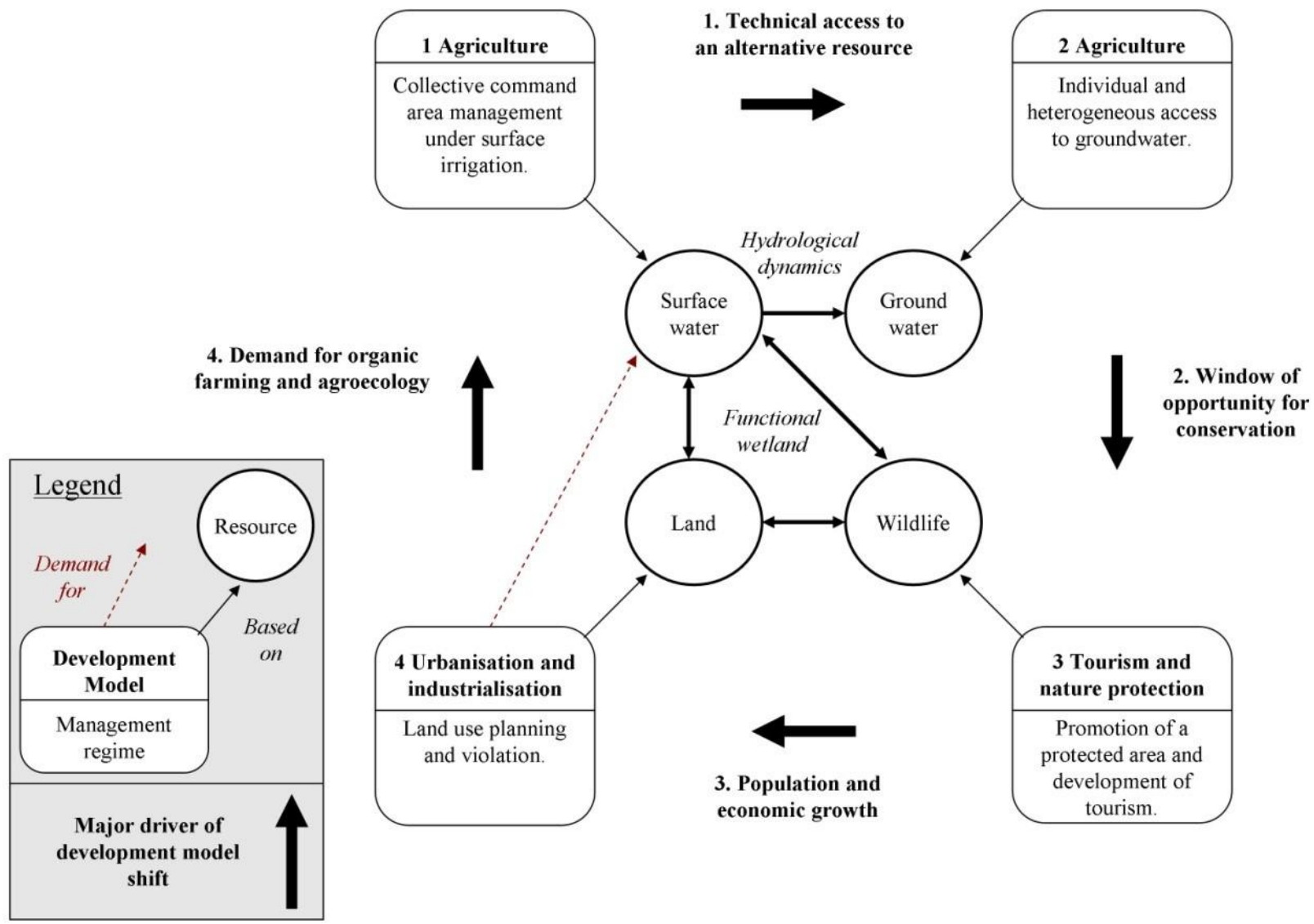

Figure 3: Synthesis scheme of the development models and management regime shifts and their interactions with natural resources of Oussudu Lake and its surrounding lands during the last 60 years.

The creation of the bird sanctuary in 2008 in Pondicherry (and 2015 in its Tamil Nadu part) is the result of the interactions of 4 factors: $(i)$ the growing demand from naturalists and public for the creation of a protected area following major industrial waste dumping in 1993 and 1998 (Abbasi and Chari, 2008). These naturalists contributed significantly to advancing the knowledge of both the ecological and social values of the lake and its surroundings and to the raising of awareness on local ecological issues, improving the focus of general population and media on greater environmental protection of the wetland; (ii) the decreasing demand for surface water used for irrigation purposes that led to increasing the submersion period of the lake and thus increased its carrying capacity for spectacular concentration of water birds in a regional context where the other wetlands usually dry quickly after the monsoon period; (iii) the growing demand for touristic activity in the surroundings of a city increasingly featured on the regional and international tourism maps. With nearly one million individuals in 2010 (Devabalane, 2016) and a record 1.6 million tourists in 2017 (according the Tourism Department) reflect that tourism is a fast-growing sector and an important source of revenue for Pondicherry (Devi, 2013). Puducherry Tourism Development Corporation (Tourism Department) has been operating recreative boats since the late 1990s (the boathouse is located on the southern bank of the lake). Thus, a third model including tourism and wildlife protection (DM3) was developed complementarily to the second agricultural 
model. The cohabitation of these two models reinforces the threats to wildlife (i.e., agricultural encroachment, habitat destruction, pollution, tourism solid waste dumping and disturbances). The bird sanctuary is an attempt to accommodate the two development models (DM2 and DM3), as two traditional activities, grazing and fishing, were banned in the bird sanctuary (Alexandar and Siva Sankar, 2013). Poaching is considered a major threat to biodiversity by a growing number of scientists and naturalists (Prusty et al., 2011; Murugesan et al., 2013; Ramachandran et al., 2017). The Narikkuravars group ("fox hunters" in Tamil) is the main local community of hunters, recently studied by Bruckert (2017). They are an ancient nomadic group (who do not have the official status of a scheduled tribe) whose livelihood depends on hunting and selling small game. When the government authorities think that these groups have been integrated and acculturated, the Narikkuravars settled in the south of Oussudu Lake still consider themselves marginalized by rest of the society (Bruckert, 2017), as they lack access to land ownership as well as due to the ban on hunting stipulated as per the Wildlife Protection Act, 1972. A strict enforcement of this law on the ground during the last decade seems to have greatly impacted the livelihood economy of this group. On the other hand, no robust data set quantifies the impact of poaching on bird populations.

\section{Period 4: Becoming an urban wetland (today)}

With both economic and population growth, a new development model based on urbanisation and industrialisation (DM4) increasingly competes with all the previous ones, and it may impact the totality of the resources. Oussudu Lake is a suburban wetland facing increasing pressure of urbanisation due to the economic and population growth of Pondicherry urban centre (Prusty et al., 2011). Surface water is no longer a key resource for most of the users. Farmers used to be powerful stakeholders in tank management but their increasing reliance on groundwater for irrigation has led to a progressive disconnection from surface water. Encroachment of the tanks themselves, of their feeding canals, issues of maintenance combined with low rainfall makes the use of tanks for irrigation more and more difficult. The rapid urbanization on the outskirts of Puducherry city has reached the command area. The dramatic increase of the local real estate market since mid-2000s facilitates land cover and land use conversion to non-agricultural purposes such as commercial and residential expansions (Venkatachalam and Begam, 2016; Venkatasubramanian, van Klink and Richard-Ferroudji., 2017). Agricultural lands are converted into settlements, public buildings and industrial zones. As already mentioned above, in 2006, a Medical College and Hospital was built in the vicinity of Oussudu Lake despite protests by the Ousteri Protection Coordination Committee (OPCC), a group composed of 21 NGOs that filed a public interest litigation (PIL) in the High Court of Tamil Nadu (High Court 2006, No.12277). Stresses related to urban sprawl may cause a shift in land use by reconverting agricultural and wildlife habitats into urban infrastructures and settlements (Roy, 2009). Since 2004, Venkatachalam and Begam (2016) estimated that about 1,100 ha of land around the lake has been converted for commercial, non-agricultural purposes, discouraging further use of the water of the lake for irrigation purpose as a feedback loop. Of course, the use of the lake as a recreational area and touristic spot might balance this ominous process. In 2015, economists estimated the recreational benefits enjoyed by visitors to Oussudu Lake to be INR 5.7 million (equivalent to US\$ 95,333) (Venkatachalam and Begam, 2016). Urbanisation is occurring presently mainly in the command area. Private organisations and panchayats (i.e., village councils) managed tree plantations (Casuarina, Eucalyptus, Prosopis and Acacia), forest restoration and organic farming on the eastern side of the lake may play the role of a buffer zone of the protected area. Overall, in this setting, a trade-off can be expected between urbanisation and tourism. 


\section{What next? Becoming a reservoir for drinking water supply?}

If the major resource of this development model is land, the increasing human population causes a surge in demand for drinkable water (Figure 3). As groundwater is overexploited threatening these fragile coastal aquifers by saline intrusion and water depletion, surface water is becoming a potential source for a complementary drinkable water supply (Sridharan and Nathan, 2017; Vincent and Violette, 2017). A survey on this subject conducted during 2002 by Water and Power Consultancy Services (India) Ltd. (WAPCOS) emphasized that the surface water available in Oussudu tank can be utilised for domestic water after being given proper treatment. Though the Conservator of Forests, Pondicherry objected on the proposal to use Oussudu water for drinking purpose, the state government decided to carry this out in the public interest. In 2015, the PWD was allowed to undertake engineering works to pump 20 million litres of surface water daily from Oussudu lake with the aim of securing urban domestic supply (PWD urban scheme for water supply 2015) potentially threatening its biodiversity conservation functions promoted by the tourism industry and conservation organisations. The Association of Puducherry Environment Protection filed a suit with the National Green Tribunal to restrain the PWD from pumping water from the lake, which is also a violation of the Wildlife Protection Act, 1972 and Biological Diversity Act, 2002. The state government proposal was objected to by the village panchayats of Tamil Nadu state located on the northern side of the tank. The National Green Tribunal issued a permanent injunction restraining withdrawal of Oussudu Lake water for drinking water purposes (NGT order vide no.154 of 2015). This situation of multiple management goals for surface water has led to conflicts. It addresses the water sharing key question: Is a trade-off possible between tourism, wildlife, and increasing drinkable water needs?

In 2020, the PWD once again has proposed to withdraw 20,000 $\mathrm{m}^{3}$ water per day for drinking purposes. The project is subject to an ongoing impact study commissioned by the BNHS. The storage capacity of the lake was estimated in 2019 about $24 \mathrm{hm}^{3}$ (A. Selles, French Geological Survey - BRGM Hyderabad, pers. comm.). According, first estimates from BRGM's hydrological modelling work indicate a monthly withdrawal of $0.6 \mathrm{hm}^{3}$ water, as projected by the PWD, would have relatively low impact on the open water surface $(<10 \%)$ when the lake is filled to its full capacity in January (as long as little water is used for irrigation). However, years when the lake is only half-filled in January (such as 2019), the PWD withdrawal could have an impact as early as April (15-20\%) and considerably reduce the open water area in May (>70\%). Using surface water for drinking water supply may impact the water outflow and then the reduction of water levels and the increase of the duration of the drying period in summer and possibly in the early monsoon season if the rainfalls are long awaited. Such a process could, with the next flooding season, boost the aquatic vegetation and diversity and attract water birds and provide habitats for fish and other species. But, from a tourism activity perspective, it could reduce the duration of boating possibilities by reducing water levels and open water bodies, and bird watching interest if the whole area is dry for several months.

From a management perspective, dry periods are also useful because they enable mechanic desilting, removal of invasive fish or plant species (i.e., Ipomea carnea, Prosopsis juliflora) and eventually creation or maintenance of bird breeding places such as islands. If the managers decide to turn Oussudu Lake into a major regional nesting place for Spot-billed pelicans (Pelecanus philippensis), Painted storks (Mycteria leucocephala) and tree-nesting herons by creating a set of islands planted with trees (as they started to suddenly build 10 islands in July 2019 taking advantage 
of the exceptional drying-up of the lake in mid-June), the level of nutrients in the water could dramatically increase and this could be an opportunity to reconnect farmers to their tank by providing them nutrient-rich water for irrigation. Such a process could, as in Vedanthangal Bird Sanctuary in Tamil Nadu (Stairmand, 1971), ensure the local community engagement in bird conservation and tourism development, as they would no longer need fertilizers in their fields. But this process could increase the water treatment cost for domestic use and could lead to a loss of "open-water-lake" high aesthetic value with the creation of a set of forested islands and to the loss of migratory waders and wintering ducks that used to be key waterbird species in Oussudu Lake. Overall, it is argued here that the use of water from Oussudu Lake for drinking water supply or irrigation purpose could have a collection of positive and negative impacts on the wetland ecosystem itself and on the bird population composition and size. A detailed study should be conducted to assess these impacts and to define the best seasonal water management options both from the perspectives of environment and tourism activities before increasing the outflow for drinking water supply or irrigating the command area.

Finally, upcoming growing social demand for organic food and agroecology promoted by environmentalists and nature activists (from Pondicherry and Auroville) can limit urban development and drinking water supply. The growing demand for organic food demand by the urban middle class is an opportunity for operating a shift toward a local food system matching collective traditional practices (surface irrigation) and sustainable farming practices. The shift toward such a new farming model might be supported by better urban planning as illustrated by the attempts of the Smart City project for Pondicherry city, a scenario planning workshops with local stakeholders (Venkatasubramanian, van Klink and Richard-Ferroudji, 2017), and works in progress regarding the regional planning (SRPFPVAC, 2012).

\section{Discussion}

Drawing from the SES analysis and historical political ecology of this wetland, five key points are identified. These points are likely to improve future integrated conservation and development policies, practices and programmes.

First, the bird sanctuary established only on the perimeter of the water body does not constitute a functional ecosystem and operates a "black boxing" of the catchment and command area. Ecological links between the lake and the surrounding agricultural landscape are not taken into consideration by any legal measure. Oussudu Lake and the surrounding paddy fields, ponds, canals, settlements and tanks constitute an interconnected hydro-ecological system (Manimekhalan et al., 2005). If the bird sanctuary is a legal protection that may protect the lake itself from the urbanisation pressure, the surrounding farmlands do not resist the pressure of urbanisation and the high demand for land, waste dumping, and so on, and this process could erode the attractiveness of the sanctuary for water birds by destroying its associated feeding grounds located in farmed and grazed lands (i.e., especially for granivorous ducks, and herons). Oussudu Lake is also dependent on the inflow of water coming from Veedur dam in Tamil Nadu. This hydrological connexion may affect the water quality and the ecological dynamics of the lake (Abbasi and Chari, 2008). Major issues of water management at watershed scale are not found to be addressed while direct threats,

\footnotetext{
${ }^{2}$ In cybernetic, a "black box" is a system for which we can merely observe the inputs and outputs, but not the internal mechanisms and how it is running.
} 
such as poaching, encroachment, habitat destruction, solid waste dumping, industrial pollution, weed invasion and siltation, are often highlighted (Dhanam, Sathya and Elayaraj, 2016; Padmavathy, Alexandar and Anbarashan, 2010; Murugesan et al., 2013). If immediate protection measures focusing on the lake such as zones free from plastic, fences to prevent encroachment, and law enforcement against poaching are recommended (Prusty et al., 2011), there is also an urgent need to adopt a regional-scale approach to deal with global threats, such as urbanisation, water scarcity. The necessity of a holistic approach at the watershed level taking into consideration a functional wetland including wildlife habitats, hydrological cycles and social dynamics is affirmed by many scientists (Abbasi, 1997; Prusty et al., 2011; Bassi and Kumar, 2012; Kumar, 2013). However, the bird sanctuary might appear as a failure of "land sparing" in a system where human and environmental components are strongly connected. To assess the impact of human activities and to better understand dynamics on the regional scale, long-term monitoring is recommended. Overall, accurate data on land cover/land use dynamics and changes in biodiversity are found to be missing. Such a study may provide key information for future decisions in an integrated management plan for Oussudu Lake.

Second, there is a need to provide the vulnerable communities still dependent on Oussudu Lake for their livelihood with a voice. According to respondent scientists, birdwatchers and environmental activists, poaching is a major issue for bird conservation in this area. The Narikkuravars have been found to hunt several species of birds at Oussudu Lake, both migratory and resident (Prusty et al. 2011). If the status of the lake is influencing hunters' choices, the law enforcement in the bird sanctuary does not seem to have discouraged illegal hunting. Although causing direct harm to wildlife, the real impact of such practices on biodiversity remains understudied. Since farmers are now relying on groundwater for irrigation, no strong stakeholder is currently depending on Oussudu Lake with a willingness to maintain its hydrological function. Oussudu Lake is, therefore, even more exposed to external pressures. There is an urgent need to give voice to vulnerable stakeholders such as the Narikkuravars who are deprived of their main activity without any alternative being proposed by the government (Bruckert, 2017) or local livestock breeders and water users. Systematic exclusion of human activities from protected areas often relies on an erroneous perception of the local communities' role in maintaining wetland functions (e.g., by exporting organic matter with reed harvesting or grazing). Their prohibition may cause mismanagement of the protected area (Gopal, 1991; Mathevet et al., 2015). Participatory approaches are a way to organise the decision-making process so as to include the local communities. The transition towards green policies implies interaction between social organizations, beliefs, values and knowledge on the one hand, and the institutions that shape individual and collective choices on the other (Ostrom, 2005). These interactions provide the basis for thinking the management of urban lake commons (Nagendra and Ostrom, 2014) and for designing a new social contract among citizens, states and international companies, based on their duties and responsibility. To conserve biodiversity, one must address not only biodiversity hotspots and protected areas but also the production and urban landscapes that host a major part of biodiversity. Alternative production and trading systems are thus paramount. In addition, linking an understanding of multi-layered social-ecological dynamics with participatory studies could generate socially robust and ecologically sound solutions (Venkatasubramanian, van Klink and Richard-Ferroudji, 2017). Conservation scientists can help identify these solutions in a fully integrative framework with decision makers and resource users. 
Third, the history of this wetland shows how bird sanctuary labelling to attract tourists may lead to elusive economic gains and obvious impacts on biodiversity (i.e., disturbance leading to reduce bird presence while food and habitats are there in abundance during both wintering and breeding seasons). As restrictions inside the protected area are not respected (i.e., boat free zone and forbidden hunting and fishing activities), Oussudu Lake seems to be for some investigators a "paper park". A protected area that does exist on maps and in legislation, but human activities may impact the real protection on the ground. The change in governance from community management (collective irrigation and associated uses) to state management has put on the back burner the traditional users of the lake and resources (i.e., fish, bird, silt, fodder). The two governmental services (i.e., forest and wildlife services) that are responsible for lake maintenance and control are unable to be effective due to the lack of coordination between the two states (Tamil Nadu and Pondicherry Union Territory), and with other departments (e.g., Public Works and Tourism Departments). In such a context, bird sanctuary can appear mostly as a label to attract visitors and enhance tourism in the Pondicherry region even with reinforcement of the law concerning fishing and poaching. Regulating tourism activity to find a trade-off with conservation purposes is crucial for the quality of the wetland and its contribution to migratory bird conservation in Asia, especially wintering ducks.

Fourth, like other works on USA and European wetlands (Hollander, 2005; Mathevet, 2004), this study highlights how the construction of a place as "natural" or "key resource" impacts its use, conservation and management. The recent change of the terms in use to designate the area from "Ousteri or Oussudu tank" to "Oussudu Lake" illustrates the shift in perception of the water body and its associated uses; over the last decade the lake has transitioned into a peri-urban green space and "wild place" used for recreation and bird watching, like other lakes in India (D'Souza and Nagendra, 2011), Sri Lanka (Hettiarachchi et al., 2019) or Europe (Salizzoni et al., 2020). Overall, it can be said that the power over natural resources of this wetland moved from Public Work Department and farmers to the Forest and Tourism Departments, as we have gradually moved over time from a vision of "lake for farmers and natural resource's users" to a "lake for biodiversity and tourists", which is presently dominating. However, in the shadow of this last vision, another vision is hidden: "A lake without people but for birds" promoted by naturalists and activists based on whatever the intensity level of management actions they recommend. These visions are coexisting and fed by the development models and, in turn, contribute to feeding predominant discourse on resource management and its shifts into new regimes that each time exclude the most marginalized actors (i.e., hunting tribes) or reduce the well-being of vulnerable ones by restricting access to benefits provided to them by the wetland's resources (i.e., fishers, livestock breeders) without any consideration for their potential positive contributions in the wetland dynamics. Such power transformations shape the larger social-ecological system, which moves from a "multi-use wetland" consisting of a high diversity and changing wild habitats to a "specialized wetland" for bird conservation and tourism, consisting of "natural" habitats under control.

Fifth, change in Oussudu Lake management goals drive vulnerability transfers at three levels: social, environmental and regional. The social transfer of vulnerability occurred when the bird sanctuary was declared and hunters and fishermen from local tribal communities became poachers. The protected area and law reinforcement on the ground put a vulnerable community (hunters) into an even more precarious socio-economic situation (they became poachers). Environmental transfer of vulnerability may happen in the future if the lake becomes a reservoir for potable water. By allocating all the water resources to domestic purposes the well-being of the wetland's biodiversity 
could change dramatically. Such a decision may also bring regional vulnerability regarding the importance of water conflicts on the watershed scale. For decades, a conflict over Cauvery water has been going on between Tamil Nadu and Karnataka states. In this arm wrestling between states for water sharing, Pondicherry has a vulnerable position as it is downstream from and less economically powerful than Tamil Nadu. The situation worsens in a period of water scarcity. Water resources allocation will determine who is able to use water, how, when and where. What sustainable management is there to answer the increasing need for drinkable water? What allocation arrangements can be designed to adapt to growing change in conditions in the face of the rise of economic, ecological and socio-cultural values of wetlands and associated wildlife? These questions need our urgent attention.

\section{Conclusion}

Changes in institutions, tank crisis and the shift from commons to private irrigation systems call for rethinking water management. Groundwater is overexploited, and surface water became the source of inter-state conflicts. The bird sanctuary provides a legal protection to wildlife but converges the focus on water birds rather than water. Birds are a flagship fauna of wetland conservation. Hydrological dynamics and the water quality are key drivers of the ecosystem. Rethinking water management means conceiving water as a central element of concern. What quality and quantity of water do we want for humans and biodiversity? A trade-off on water between different users has to be found on different scales: How to share water in the tank and at the watershed level? If drinkable water becomes the major issue in the near future, is it still compatible with regulated tourism and does it still meet conservation purposes?

The Oussudu Lake wetland has undergone major social-ecological transformation that emphasizes a set of lessons that may have broader application in management of wetlands near fast expanding cities such as in India or Southeast Asia. Thus, conservation scientists, NGOs and decision-makers should pay attention to these lessons learnt, and this study should help them identify barriers to adaptation or transformation. The lack of systemic (multi-scales and multi-networks) and regional and multidisciplinary approaches to environmental change do not allow for addressing the socialcultural-political structural causes of vulnerability nor their transfers to other areas, social groups or biodiversity (Barreteau et al., 2020). The most promising research areas for implementing an integrated conservation and development approach on these integrated issues of water allocation and biodiversity conservation are: $(i)$ recognising the tank as an ecosystem and not only a water resource for irrigation or potable waters but also fully considering it and its surroundings as a social-ecological system; (ii) studying how local users and inhabitants perceive and value the wetland and its resources along with its governance system; (iii) empowering the marginalised sectors of society by improving social knowledge of vulnerability transfers and systemic understanding of social-ecological interdependencies; (iv) exploring how politics under local resource management arrangements may tackle the key issue of individual/collective responsibility for conservation and development actions and their consequences; $(v)$ maintaining this urban lake commons through polycentric arrangements and public-community partnerships. We call for implementing robust monitoring of both ecological and social dimensions and for further research work on how to design and implement effective public policy and community-based management of wetlands in peri-urban and urban contexts. 


\section{Acknowledgments}

The authors would like to thank the Forest Departments of Tamil Nadu and Pondicherry for permitting the fieldwork, the French Institute of Pondicherry (IFP and the WaterPondy project), and the Agence Française de Développement (AFD) for the research grant and logistic support of this work (RUSE project). The views expressed in this article are those of the authors and do not necessarily reflect the views of IFP or AFD. Thanks also go to interviewees, local scientists, Adrien Selles (French Geological Survey, BRGM, Hyderabad), NGOs and local users, who always welcomed the investigators and authors.

\section{References}

Abbasi, S.A. (1997). Wetlands of India: ecology and threats. Vol. 1: the ecology and the exploitation of typical South Indian wetlands. New Delhi: Discovery Publishing House.

Abbasi, S.A. and Chari, K.B. (2008). Environmental Management of Urban Lakes: With Special Reference to Oussudu. New Delhi : Discovery Publishing House.

Adiceam, E. (1966). La géographie de l'irrigation dans le Tanilnad. Paris: Publications de l'Ecole Française d'Extrême-Orient.

Alexandar, R. and Siva Sankar, R. (2013). Diversity of Fish Fauna and Their Threats in Ousteri Lake, Puducherry, India. World Journal of Zoology, 8(2): 124.

Anderies, J.M., Folke C., Walker B. and Ostrom, E. (2013). Aligning key concepts for global change policy: robustness, resilience, and sustainability. Ecology and Society, 18: 8.

Antony, F.C. (Ed.). (1982). Agriculture and Irrigation in Gazetteer of India - Union Territory of Pondicherry. Volume-I. Administration of Union Territory of Pondicherry, pp. 408-446.

Atkins, W.S. (2001). Tank Rehabilitation Project Puducherry Baseline Survey. Chennai, Tamil Nadu.

Aubriot, O. (Ed.). (2013). Tank and well irrigation crisis: spatial, environmental and social issues. Cases in Puducherry and Villupuram districts (South India). Delhi: Concept Publishing Company.

Aubriot, O. and Prabhakar, I. (2011). Water institutions and the 'revival' of tanks in South India: what is at stake locally? Water Alternatives, 4(3): 325-346.

Balasubramanian, R. and Selvaraj, K.N. (2003). Poverty, Private Property and Common Pool Resource Management: The Case of Irrigation Tanks in South India. (Working Paper No. 2). South Asian Network for Development and Environmental Economics. Kathmandu, Nepal.

Barrat, J.M. (1999). Part 1 - Hydrogeological Study - Report on Hydrogeologist Expert Mission 24March - 8 April 1999. Tank Rehabilitation Project. Pondicherry, Unpublished.

Barreteau, O., Anderies, J.M., Guerbois, C., Quinn, T., Therville, C., Mathevet, R. and Bousquet, F. (2020). Transfers of vulnerability through adaptation plan implementation: An analysis based on networks of feedback control loops. Ecology and Society, 25(2): 3.

Bassi, N. and Kumar, M.D. (2012). Addressing the civic challenges: perspective on institutional change for sustainable urban water management in India. Environ. Urban Asia, 3: 165-183.

Bassi, N., Kumar, M.D., Sharma, A. and Pardha-Saradhi, P. (2014). Status of Wetlands in India: A Review of Extent, Ecosystem Benefits, Threats and Management Strategies. Journal of Hydrology: Regional Studies, 2: 1-19.

Berkes F., and Folke, C. (Eds.). (1998). Linking social and ecological systems: management practices and social mechanisms for building resilience. Cambridge: Cambridge University Press. 
Blaikie, P. and Brookfield, H. (Eds.). (1987). Land degradation and society. London: Methuen.

Bruckert, M. (2017). Animal sacrifice and hunting in contemporary India. Activity Report \& Preliminary results. Puducherry: Fondation Maison des Sciences de l'Homme (FMSH), École Française d'Extrême-Orient (EFEO).

D'Souza, R. and Nagendra, H. (2011). Changes in public commons as a consequence of urbanisation: the Agara lake in Bangalore, India. Environmental Management, 47: 840-850.

Davidar, P. (2011). Wetland birds of Pondicherry Region. A pictorial field guide. Puducherry, ECOS.

Davidson, N.C. (2014). How much wetland has the world lost? Long-term and recent trends in global wetland area. Marine and Freshwater Research, 65 (10): 934-941.

Devabalane, E. (2016). Lake Tourism in Ousteri. The great experience. Puducherry: Puducherry Co-op. Book Society Ltd.

Devi, R.U. (2013). An evaluative study of tourism industry in Puducherry, U.T. of India. International Journal of Innovative Research \& Development, 2 (6): 80-103.

Dhanam, S., Sathya, A. and Elayaraj, B. (2016). Study of Physico-Chemical Parameters and Phytoplankton Diversity of Ousteri Lake in Puducherry. World Scientific News, 54: 153-164.

Doshi, S. and Ranganathan, M. (2017). Contesting the Unethical City: Land Dispossession and Corruption Narratives in Urban India. Annals of the American Association of Geographers, 107 (1): 183-199.

Foote, A.L., Pandey, S. and Krogman, N.T. (1996). Processes of Wetland Loss in India. Environmental Conservation, 23(1): 45-54.

Gallopín, G.C., Gutman, P. and Maletta, H. (1989). Global impoverishment, sustainable development and the environment - a conceptual approach. International Social Science Journal, 41(3): 375-397.

Ghermandi, A., Van den Bergh J.C.J.M., Brander L.M., De Groot, H.L.F and Nunes, P.A.L.D. (2010). Values of natural and human-made wetlands: a meta-analysis. Water Resources Research, 46(12): 1-12.

Glaux, J.P. (1972). Monographie d'un village de l'Etat de Pondichéry (Inde). Bulletin de l'Association de géographes français, 49(402): 347-49.

Gopal, B. (1991). Wetland (mis)management by keeping people out: two examples from India. Landscape Urban Planning, 20: 53-59.

Hettiarachchi, M., Morrison, T.H. and McAlpine, C. (2019). Power, politics and policy in the appropriation of urban wetlands: the critical case of Sri Lanka. The Journal of Peasant Studies, 46(4): 729-746.

Hollander, G. (2005). The material and symbolic role of the Everglades in U.S. national politics. Political Geography, 24(4): 449-475.

Hu, S., Niu, Z., Chen, Y., Li, L. and Zhang H. (2017). Global wetlands: potential distribution, wetland loss, and status. Science of the Total Environment, 586: 319-327.

Janakarajan, S. (2004). Irrigation: The development of an agro-ecological crisis. In Harriss-White, B. and Janakarajan, S. (Eds), Rural India facing the 21st century: Essays on long term village change and recent development policy, pp. 59-77. London: Anthem Press.

Jhunjhunwala, S. (1998). The Ornithological importance of Oussudu lake and Bahour lake: A study of the habitat preferences of their waterfowland waders. M.Sc. Dissertation. Salim Ali School of Ecology and Environmental Sciences, Pondicherry University, Puducherry, India.

Kates, R. (2011). What kind of a science is sustainability science? Proceedings of the National Academy of Sciences of the United States of America, 108(49): 19449-19450. 
Kumar, M.D. (2013). Water Insecurity and Climate Variabilityin India: Theoretical Understanding and Practical Programming. Hyderabad: Institute for Resource Analysis and Policy and South Asia Consortium for Interdisciplinary Water Resources Studies.

Kumaran, B., Jagannathan, I., and Nadarajan, J. (2012). Status of avifauna of Ousudu lake, Puducherry, India. International Journal of Research in BioSciences, 1(2): 38-46.

Lee, J. (2014). The governance of wetland ecosystems and the promotion of transboundary water cooperation - opportunities presented by the Ramsar Convention. Water International, 40(1): 33-47.

Lele, S. and Sengupta, M.B. (2018). From lakes as urban commons to integrated lake-water governance: the case of Bengaluru's urban water bodies. South Asian Water Studies, 8(1): 526.

Malty, E. and Barker, T. (2009). The Wetlands Handbook. Oxford: Wiley-Blackwell.

Manimekhalan, M., Yoganand, T.R.K., Rajan, V., Amruth, M., Ilangovan, K. and Sharma, C.B.S.R. (2005). Biodiversity and ecology of two endangered wetlands of Tamil Nadu coastKaluveli and Osuteri. In: Ramachandra, T.V. and C.R. Murthy, eds., Aquatic Ecosystems: Conservation, Restoration, and Management, New Delhi, Kaveri Books, pp.131-144.

Marius-Gnanou, K. (1992). La Révolution Verte et La Maîtrise de l'espace Agricole: Le Cas de La Région de Pondichéry (Inde Méridionale). Cahiers d'outre-Mer, 45(178): 189-212.

Matamanda, A.R., Chirisa, I., Makumuri, B.B., Kaduwo, P. and Mhlanga, M., (2018). Harare's Deteriorating Wetlands: Why Sound Policies and Legislations Are Not Enough. Case Studies in the Environment, 2(1): 1-11.

Mathevet, R. (2004). Camargue incertaine. Sciences, usages et natures. Paris : Buchet-Chastel.

Mathevet, R., Allouche, A., Nicolas, L., Mitroi, V., Fabricius, C., Guerbois, C. and Anderies, J.M., (2018). A Conceptual Framework for Heuristic Progress in Exploring Management Regime Shifts in Biodiversity Conservation and Climate Change Adaptation of Coastal Areas. Sustainability, 10: 4171.

Mathevet, R., Peluso, N., Couespel, A. and Robbins, P. (2015). Using Historical Political Ecology to Understand the Present: Water, Reeds and Biodiversity in the Camargue Biosphere Reserve (Southern France). Ecology and Society, 20(4): 17.

Miho, A., (2018). Building activities within protected areas are often unfriendly and unsustainable to wetland conservation - Albanian case. Thalassia Salentina, 40(2): 91-112.

Moore, J.W., Schindler, D.E., Scheuerell, M.D., Smith, D. and Fordge, J., (2003). Lake Eutrophication at the Urban Fringe, Seattle Region, USA. Ambio, 21(1): 12-18.

Moore, P.D. (2006). Wetlands. New York: Chelsea House.

Murugesan, M., Rachna Chandra, B., Prusty, A.K. and Arun, P.R. (2013). Avifauna of the Oussudu Lake and its environs, Puducherry, India and Conservation Concern. Bird Populations, 12: 19-29.

Nagendra, H. and Ostrom, E., (2014). Applying the social-ecological system framework to the diagnosis of urban lake commons in Bangalore, India. Ecology and Society, 19(2): 67.

Neumann, R.P. (2005). Making political ecology. London: Hodder Arnold.

Ostrom, E. (2005). Understanding Institutional Diversity. Princeton, USA: Princeton University Press.

Padmavathy, A., Alexandar, R. and Anbarashan, M. (2010). Diversity of Birds in Ousteri Wetland, Puducherry, India. Our Nature, 8(1): 247-253.

Palanisami, K. and Balasubramanian, R. (1998). Common property and private prosperity: Tanks vs private wells in Tamil Nadu. Indian Journal of Agricultural Economics, 53(4): 600-613. 
Perennou, C. (1990). Peuplements d'oiseaux aquatiques en milieu anthropisé : un exemple. Les plaines de la Cote de Coromandel (Inde du Sud-Est). PhD thesis, Lyon, Université Claude Bernard, Lyon I, France.

Prabhakar, P.I. (2007). Socio-cultural intimidation on the emerging irrigation institutions. The $4^{\text {th }}$ Asian Regional Conference \& $10^{\text {th }}$ International Seminar on Participatory Irrigation Management, Tehran, Iran.

Prasad, S.N., Ramachandra, T.V., Ahalya N., Sengupta T., Kumar, A., Tiwari, A.K., Vijayan, V.S. and Vijayan, L. (2002). Conservation of Wetlands of India-a Review. Tropical Ecology, 43(1): 173-186.

Prusty, B.A.K., Arun, P.R., Bhupathy, S., Murugesan, M. and Chandra, R. (2011). Comprehensive Management Action Plan for Conservation of Oussudu Sanctuary, Puducherry. Sálim Ali Centre for Ornithology and Natural History (SACON), Moongilpallam, Anaikatty (PO), Coimbatore - 641108, Tamil Nadu, India.

Ramachandran, R., Kumar, A., Gopi Sundar, K.S. and Singh Bhalla, R. (2017). Hunting or Habitat? Drivers of Waterbird Abundance and Community Structure in Agricultural Wetlands of Southern India. Ambio, 46(5): 613-20.

Robbins, P. (2012). Political ecology: a critical introduction. Second edition. Chichester, UK: Wiley.

Roy, A. (2009). Why India Cannot Plan Its Cities: Informality, Insurgence and the Idiom of Urbanization. Planning Theory, 8(1):76-87.

Russi, D., Ten Brink, P., Farmer, A., Badura, T., Coates, D., Förster, J., Kumar, R. and Davidson, N. (2012). The Economics of Ecosystems and Biodiversity for Water and Wetlands. Final Consultation Draft. UNEP, Hyderabad, India.

Salizzoni, E., Pérez-Campana, R., Alcalde-Rodriguez, F., and Talavera-Garcia, R., (2020). Local Planning Practice towards Resilience: Insights from the Adaptive Co-Management and Design of a Mediterranean Wetland. Sustainability, 12(7): 2900.

Scott, D.A. (1989). A directory of Asian wetlands. Gland, Switzerland: IUCN.

SER (2016). State of Environment Report for Tamil Nadu. Centre of Excellence in Environmental Economics, Madras School of Economic. Chennai, Tamil Nadu.

Shaktivadivel, R., Gomathinayagam, P. and Shah, T. (2004). Rejuvenating irrigation tanks through local institutions. Economic and Political Weekly, 39(31): 3521-3526.

Sharma, C.B.S.R. (1997). Ecography of small water bodies. A Pilot study of five irrigation tanks and coastal wetland in Tamil Nadu and Pondicherry. pp. 45-55.

Smith, R.J., Muir, R.D.J., Walpole, M.J., Balmford, A. and Leader-Williams, N. (2003). Governance and the loss of biodiversity. Nature, 426: 67-70.

Sridharan, M. and Nathan, D.S. (2017). Groundwater Quality Assessment for Domestic and Agriculture Purposes in Puducherry Region. Applied Water Science, 7(7): 4037-53.

SRPFPVAC (2012). Sustainable Regional Planning Framework for Puducherry, Villupuram, Auroville, Cuddalore. Final Report. ADEME, INTACH, PondyCAN, Puducherry, India.

Stairmand, D.A. (1971). Vedanthangal. Newsletter for Birdwatchers, 11(7): 6-9.

Steffen, W., Sanderson, R.A., Tyson, P.D., Jäger, J., Matson, P.A., Moore III, B., Oldfield, F., Richardson, K., Schellnhuber, H.J., Turner, B.L. and Wasson, R.J. (2004). Global change and the earth system: a planet under pressure. Berlin: Springer Science \& Business Media.

Surya, S. (2016). Landscape Ecological Urbanism for Restoration of Pallikaranai Marsh Land, Chennai, Tamil Nadu. Procedia Technology, 24: 1819-1826.

The Hindu (2019). Puducherry's major lakes suffer from neglect, exploitation. June 21, 2019. 
TRPP (2004). Tank Rehabilitation Project Puducherry (1998-2004). Government of Puducherry, Public Work Department, Agricultural Department. European Union Funding Report. Puducherry, India.

Turner, R.K., Van Der Bergh, J.C.J.M., Soderqvist, T., Barendregt, A., van der Straaten, J., Maltby, E. and van Ierland, E.C. (2000). Ecological-economic analysis of wetlands: scientific integration for management and policy. Ecological Economics, 35: 7-23.

Venkatachalam, L. and Begam, Z.I. (2016). Economic Valuation of Ecosystem Services: A Case Study of Ousteri Wetland, Puducherry. The Economics of Ecosystems and Biodiversity India Initiative. Chennai, GIZ India.

Venkatasubramanian, G., van Klink, I. and Richard-Ferroudji, A. (2017). Scenarios for water and agriculture in Pondicherry region. Puducherry: French Institute of Pondicherry, Department of Science Technology and Environment.

Vincent, A., and Violette, S. (2017). Why Seawater Intrusion Has Not Yet Occurred in the Kaluvelli-Pondicherry Basin, Tamil Nadu, India. Hydrogeology Journal, 25(6): 1893-1907. 